Studia i Materiały, 2/2017 (25), cz. 2: 66-73

\title{
Contemporary Trends in Management Education versus Student Expectations
}

\author{
Agnieszka Postuła*
}

\begin{abstract}
Modern universities are experiencing constant changes which are extremely meaningful nowadays. These changes reflect on the further directions of the management education development in a broad context. This paper presents the results of research on the condition of management education in the students' perception. The methodology of this research was inspired by ethnography and based on anthropological interviews (12 conducted with first-year students and 13 with last-year students). They pointed out some university domains insufficiently supervised by the academic authorities both financially and mentally. The conclusions presented in the text are based on the expectations of students confronted with the current situation. They clearly indicate a gap in the educational system which is based mainly on the turnover of the traditional university values.
\end{abstract}

Keywords: management education, students' expectations, academic values, ethnography, educational system

Submitted: 06.07.17 | Accepted: 28.12.17

\section{Współczesne trendy w edukacji menedżerskiej a oczekiwania studentów}

Zmiany zachodzace we wspótczesnych uczelniach sktaniaja do refleksji nad dalszymi kierunkami rozwoju edukacji menedżerskiej w szerokim kontekście. Autorka prezentuje wyniki badań nad stanem edukacji menedżerskiej w opinii studentów. W badaniu inspirowanym metodami etnograficznymi wzięli udział studenci szkót zarządzania pierwszego roku studiów licencjackich i ostatniego roku studiów magisterskich. Wskazali obszary uczelni niedostatecznie doinwestowane przez władze akademickie zarówno finansowo, jak i mentalnie. Wnioski zaprezentowane $w$ tekście oparto na konfrontacji oczekiwań studentów ze stanem faktycznym. Jednoznacznie wskazuja one na lukę w systemie edukacyjnym, która bazuje głównie na zmianie tradycyjnych wartości uniwersyteckich.

Słowa kluczowe: edukacja menedżerska, oczekiwania studentów, wartości akademickie, etnografia, system edukacyjny

Nadesłany: 06.07.17 | Zaakceptowany do druku: 28.12.17

JEL: A20, I21, I23

\footnotetext{
Agnieszka Postuła, dr - Wydział Zarządzania Uniwersytetu Warszawskiego

Adres do korespondencji: Wydział Zarządzania Uniwersytetu Warszawskiego, ul. Szturmowa 1/3, 02-678 Warszawa, e-mail: apostula@wz.uw.edu.pl.
} 


\section{Introduction}

The current developments in management education inspire reflections on its actual condition and suggest taking corrective action in this respect forthwith Koźmiński (2011) identified the areas of the most common threats that undoubtedly have a strong influence on the direction of the university development. The first essential factor that he mentions is the popularization and availability of management schools. He claims that the prevalence of fields of study that are no longer directly associated with business is the most disturbing phenomenon. Representatives of professions or occupations such as art historians, chefs and farmers attend university courses to gain management knowledge in order to become better entrepreneurs or managers. The second phenomenon adversely affecting the future of management education and relating to the first one is the definite specification of student needs. This involves establishing study fields that Andrzej Koźmiński calls "exotic", including show business, tourism or art management. Another problem also linked to the popularity of business schools concerns schools being created in locations where they have low legitimacy to educate future managers, e.g. poor or developing countries or even countries mired in corruption and an authoritarian regime. Constantly rising costs of management education represent the last obstacle to the correct development thereof. Educating future managers is a very expensive activity, still requiring more resources.

Thus questions arise about the future and development directions of management education considered at many levels. Management education is criticized not only for its specific forms (D'Andrea Tyson, 2005), with an excessive influence of students on educational methods being questioned, but also for the organization of the university as a whole (WieczorkowskaWierzbińska, 2011). In analysing an entrepreneurial and liberal university, Krzysztof Leja (2013) indicates that the future of the university lies in its added value created jointly with its internal and external stakeholders. This means integrating the academy with its environment, controlling their interactions, and an overlap between academic and market social roles. All these phenomena are associated with a special position of the economy and management in the modern world. The $20^{\text {th }}$ century is known as the era of managers (Koźmiński, 2008) who gradually took over control of many economic areas and all forms of organized social life (Kostera, 2011).

This paper embraces the student perspective. Therefore, expectations of lastyear management students towards universities and the studying process will be analysed and interpreted.

\section{Research method}

The evidence was obtained from the ongoing ethnographic research. Ethnography, being a specific methodology, is a natural consequence of the adopted view on the social reality. This implies that the evidence collected and presented in this paper and the conclusions drawn on this basis may provide an input for multidimensional discussions about the future of the university, yet will not feed into establishing one and only right course of action (Willis, 2005).

Traditionally qualitative methods (anthropological interview) formed the basis for that research (Kostera, 2005). An anthropological interview is a fundamental research tool helping to collect evidence on the ground. It is an undirected (nonstandardized and unstructured) conversation aiming to induce interviewees to freely talk about their surrounding reality. The researcher's "anthropological mindset" (Czarniawska-Joerges, 1992) is a desirable state of mind helping to see the stories heard as completely new and interesting phenomena on the one hand. On the other hand, it allows for asking such questioning that do not suggest anything to interviewees but enable them to tell their own stories.

The interviews were conducted with first- and fifth-year students of the business schools in Poland. The idea was to compare the approach of younger people who were just starting their higher education with that of people who already knew what that process involved. This paper particularly highlights interviews with older students who hold much more crystallized views on the studying process and who have already experienced all benefits and hardships of academic life. 12 interviews with first-year students and 13 interviews with fifth-year 
students have been analysed, most of them lasting from half an hour to an hour.

The study material will also be supported by the author's long experience as a university teacher.

\section{Management education}

Contemporary management education both in Poland and in the world is still guided by the long-known idea of functionalist management initiated by F. Taylor (1911). The greatest emphasis is put on measurable indicators such as operational efficiency, employee productivity, profit, etc. Although the Polish and international approaches slightly differ, with our eyes fixed on the West, we have not noticed that the direct adaptations of western solutions do not necessarily head in the right direction. Fortunately, we are slowly beginning to see that the transferred patterns are not good for various reasons. These, certainly, can be measured by employing purely functionalist methods (profit and efficiency) but the greatest losses are sustained in other areas. Many other spheres such as spirituality or values suffer as a result of this approach. We cannot resist this trend as it is very strong and, when analysed further, may be said to be very versatile. The pressure on perceiving the reality chiefly in economic terms comes from different sides (Shaw, 2013). Therefore, it is so difficult for universities to distance themselves from this trend. Fortunately, there are many positive examples that should now determine a course of further action for managers.

The roles of education include looking closely at the reality and drawing conclusions, yet this is only one direction. Clinging to the financial or economic aspect is also notable in this domain. It is understandable why business schools are still following these trends. Pursuing the "there is a demand, there is supply" principle, universities respond to the interest among students involved in various education forms with an adequate offer. The question is: where are we going? Careful observation of the reality suggests that numerous surprising regularities may be noticed at the same time. For instance, the return of so many graduates interested in gaining further knowledge (postgraduate studies) is an astonishing fact. This proves, inter alia, a decline in the quality of education caused by an excessive number of students who cannot receive teachers' attention under well-known traditional rules (e.g. the organization of oral examinations) and by the mismatch of curricula and students real needs. Many people do not believe in their abilities to manage teams, leadership or managerial skills. Furthermore, a large number of people say that five-year studies have not given them what they expected so they return to the university for an extra "portion of knowledge". This return is unlikely to help them dispel their doubts as the core of the problem lies much more deeply. The failures and unbelief among young people frequently derive from the system of management education which is currently heading towards a dead end. It is a closed road the end of which many people still cannot see. With so many signals from outside (decline in the quality of education due to the recruitment of students who do not meet appropriate criteria, return to universities to expand knowledge, disappointment with employee attitudes among employers, etc.), disregard for these phenomena by the university authorities is staggering. Recalling the beginnings of the university and analysing its objectives, traditional ideas of humanism can be noted. Universities were designed to bring together open-minded, committed and creative people, foster an exchange of views, form certain attitudes and promote broadly understood development (Leja, 2013). Currently, their functions have been considerably eroded under the natural influence of external factors. Universities are trying to respond to market needs rather than creating them. A shift of the university towards the market should not be a desirable direction. Priority should be, instead, given to university activities aimed at opening the minds of young people. What should constitute a value and a course of action is educating future managers so that they do not feel lost or devoid of faith in their own abilities. The objective here is not a restoration of medieval academic standards since, for obvious reasons, this would lead to an unreasonable stagnation. Instead, we should build on the wisdom and virtues that have proved to work well for centuries. Rather than on ephemeral financial data, we should rely on values which may ensure that the university survives and determines its further development path. Taking into 
account specific higher management education institutions, at least some of them (universities included for obvious reasons) might be enabled to take actions designed to establish very open new fields of study, with the development of vocational skills left to other facilities (business, vocational, technical schools, etc.).

\section{Research findings}

The views of first-year students will be referred to briefly only in order to outline the difference between people who are just starting their academic life and adult fifthyear students who are much more aware. Beginners are mainly concerned about acquiring some management knowledge that is only a vague notion for many of them. They expect to learn certain skills and competencies (defined by them with other words) but do not possess clear knowledge about how to acquire them. Most generally, it may be stated that the largest group of first-year students is made up of people who expect the university to help them start their own business and gain knowledge and skills to conduct business effectively.

Contrary to some opinions, students perceive universities multidimensionally. Their expectations of higher education institutions may be divided into several areas. Starting with the most obvious and visible ideas and ending with the most valuable and profound ones, these are: infrastructure and different possibilities of action within the campus, forms of organization of the university work and credits, contact with the teachers and contact with other members of the student community, academic atmosphere and general values learnt at the university. All these areas will be discussed in more detail along with the quoted statements by the students.

The first aspect that is the most visible for students is the university physical structure. It includes geography, i.e. location of buildings, their spatial distribution, and the architecture and interior design (Hatch, 2002). Students did not pay attention to a particular style of buildings or specific characteristics of the layout. Instead, they talked about décor elements that were missing in their opinion. The biggest deficiency was the lack of space for group work and relaxation. Interviewees justified this by referring to collective work required by class activities but also to the need to meet their colleagues in order to share experiences, ideas and knowledge. According to them, such space might allow relaxation during breaks and spending time outside usual duties in a pleasant way. Drawing on from the experience gained at foreign universities, students even talked about rooms designed specifically for sleeping in other schools.

The FM [Faculty of Management] is super modern and beautiful, but it was even more so there, so studying was very pleasant. Of course, there was free coffee, tea, chocolate, bells and whistles, pool tables in the basement, table football, some leisure space, sofas where you could sit with that good chocolate and discuss things with the teacher who left the teaching room during breaks. (KT)

Students also pointed to such space as canteens being places for eating but also meetings their friends. They talked about creating the atmosphere by locating the university buildings so as to form a selfcontained town.

The community is definitely more integrated there, there is a completely different atmosphere, it was a typical university town where students lived at that university. You come here just to do what you're supposed to do, or possibly there are ten thousand, ten thousands of things to do, or you work so you come only to be present at these classes or to put your name on the attendance list and come back, and there people slept, ate and lived at that university. (FK)

They also spoke about small material aspects of spending time at the university, mentioning, e.g., a multifunctional ID card which allowed them to register for courses and make payments at the university, entitled them to receive discounts on public transport, buy cheap theatre tickets and register for sports activities.

The second, wider area of student expectations is the academic life organization. Indirectly, it is affected by the infrastructure described above but it consists of other elements too. An appropriate atmosphere fostering the involvement of both students and teachers is most frequently mentioned as a missing element at the university where interviewees study. Despite a relatively large number of workshops, students expect that this number will increase 
because they consider them to be a better form of obtaining knowledge in many fields and gaining experience. Almost every interviewee stressed the need to extend the choice of interactive activities available for students to take active part in. They justified their expectations referring to an opportunity to learn new skills, develop desired behaviours, the need to solve real problems and share experiences.

The truth is that the SGH [Warsaw School of Economics] has numerous scientific clubs, multitude of offers, internships in such and such company, workshops in such and such firm, certificates to confirm this and that. I just think we're lacking implementation of these theories in practice and I'm not for the theory that immediately after graduation ... I don't know if anything can be done so that just after graduation we can go out to work and be managers because I guess I don't believe it. Probably I believe in experience more. 'Cause, first of all, if I join a company, I want to know it from scratch, I can't be a manager who joins a company and wants to manage something that he totally doesn't know, who doesn't know the organization culture, people, structure or anything. (GK)

The need to interact with other people is strongly associated with another idea of the Faculty of Management students to improve the teaching process, namely through a greater link with practice. The solutions proposed by students were very interesting. They mentioned, among others, classical courses teaching, for instance, how to start a business but also establish real cooperation with various organizations, opportunities to organize (somewhat forgotten) internships and workshops, meetings with managers, organizing interesting activities on the ground, and even suggested borrowing films made by different companies for their own purposes and discussing them university meetings.

Contact with companies, entrepreneurs, activities on the ground. A conversation with a manager who'd say what it's like to run a company from the insider point of view, it would be the best. As long as you don't experience it yourself, you don't know what's really important and what you need to pay attention to. Perhaps some films shot in corporations to be watched by students. (SM)

Fifth-year students already have quite definite opinions and have presented concrete ideas on forms of development in the above areas. In their view, all forms of teamwork are valuable, a fact mentioned by the majority of interviewees.

The only thing that was good practice was the course conducted by [Professor], it was networking. We were supposed to get a credit for this course, we travelled to Masuria and there were really interesting activities, we were a group of 40 , he gave us $2-3$ hours, we had to get to know one another and say something about ourselves. Then we checked how much we knew about another person, we worked in the group all the time, there were a lot of interactions, it was really fun and brought a good effect. (SM)

According to students, such practical forms of teaching include, apart from workshops, scientific clubs as a space for exchanging experiences and meetings with entrepreneurs at the university or at specific companies. They guarantee the development of interpersonal skills, helping put into practice project management and teamwork tools discussed during lectures. They also provide an opportunity to establish a network of contacts, the point in studying for many respondents.

Let's take networking for instance. And these people who are with us, who we accept around us, who give something to us, cooperate with us, and we also give them something, that is definitely a manager's must-have. (ST)

Bringing students closer to the teachers was another interesting issue. Students feel perfectly that the contact between them and the university staff has been reduced recently. We realize that one reason why these two groups have become more separated is the work overload and numerous tasks at the university caused by the phenomena described in the introduction (e.g. prevalence of university education). At many universities, including management schools, teachers are now conducting such a considerable number of classes and lectures that the individual contact with students is practically impossible. Students, however, are themselves calling for returning to the classical studying style (characteristic of the best world universities) where this precious contact is definitely possible.

Different values and meanings represented by the university were identified as the last and extremely important aspect of student expectations. Students expressed a need to understand the meaning of the various activities at the university, which 
they often do not comprehend. They said that they studied in order to deal with the crisis in the market more effectively. They also talked about the role of the university in their lives, seeing it as an institution developing their awareness and mentality with which they will lead their further lives. Few spoke about the inspiration as a vital element of academic life that the university can offer them. They mentioned tangible and intangible opportunities provided by universities that they thought to be sometimes missing. That concerned, among others, the opportunity to establish professional contacts, gain employment, meet new people, access foreign contracts, etc. They talked about the university as a good environment, which also should be understood in many dimensions.

I guess I've got a fairly specific approach to these studies because I take what I can take for myself ... I'm also a sort of representative of stoicism, if that is meant to be so, if this is the curriculum, be it like that, I have no influence on it. I chose these studies, if I don't like them, I can change them. (KT)

As a summary of this part of the paper, another quote will be provided that I consider unique and valuable. The student pondered on the meaning of studying:

Interviewer: Why do people study?

PW: To change the Polish reality. For the better, 'cause I assume that, unfortunately, we can't change the world itself, but each of us has his own area, people we meet, company. (WP)

\section{Conclusions}

While first-year students talked mostly about skills and adaptation to the market, students already leaving the university have far more crystallized views and deeper expectations. They are to some extent disappointed with what they have received from the university. This should give decision-makers food for thought and make graduates self-confident as people who represent certain values and attitudes rather than frustrated potential "workhorses" in the labour market. To this effect, it is undoubtedly necessary to verify the current system of management education that has gone slightly too far in following the market criteria, drifting away from the basic traditional academic values (Shaw, 2013). This by no means concerns stagna- tion or a step back in the development of contemporary universities but a reflection on the possible directions of their development. Applying corporate solutions at the university, which is now a common phenomenon, does not bring expected results. There are signals from a larger environment, including the labour market where university graduates finally find themselves (Bykowski i in., 2012), and, on the other hand, students themselves see problems, as evidenced by the research results presented herein.

An attempt to formulate recommendations for remedial action for management schools by far exceeds the capacities of this text. Nevertheless, it may be possible to try to interpret student expectations and related conclusions.

Expressing concrete expectations by students is a definitely reassuring phenomenon. This means that they are aware people who set directions of their own development. Their requirements should not be regarded as a demanding attitude only (although such stances also exist) but as a sign of a mature perception of the reality surrounding them. It is difficult to estimate students' statements and divide them into more and less significant, yet I will make an attempt to compile them in a logical whole. Given that these expectations were presented in the empirical part, the physical structure of universities may be considered as a major element that has proved to be essential for students. The environment in which they spend the whole day should be conducive to learning, development of ideas, meetings, etc., but also serve relaxation and basic needs such as eating meals or spending breaks. Being at the university should not be a punishment or another unpleasant circumstance that we reasonably want to avoid but a comfortable situation which we wish to return to. It is a natural need of every human being, so often disregarded while satisfying current needs. A properly designed physical structure may have an extremely positive impact on many areas of student life that were referred to as important in the interviews. Students thought that relationships both among one another and with the teachers were valuable. Spending more time on all kinds of meetings and creating space for this purpose could result in new ideas and personal and professional development of mem- 
bers of such groups. This would foster the development of a positive atmosphere of cooperation and experience sharing, always leading to interesting solutions. Meetings of students and teachers at workshops and other interactive activities stimulate thinking, help take up various activities and are conducive to memorizing new knowledge and skills. Only such activities may form the basis for building and supporting the values mentioned by the students. They will give room for inspiring young people but also stimulate further research investigations. They will enable the development of all parties involved in such mind-opening actions. Organizing meetings and space for the exchange of ideas will provide an opportunity for real study regarded by the students as "the exploration of interesting topics" (ST). The university is a place that is created primarily by students and develops their mentality and awareness in return. Therefore, it is crucial to configure the interaction between these agents in a proper way. Figure 1 provides an overview of the areas discussed.

Figure 1. Students' expectations with regard to management education

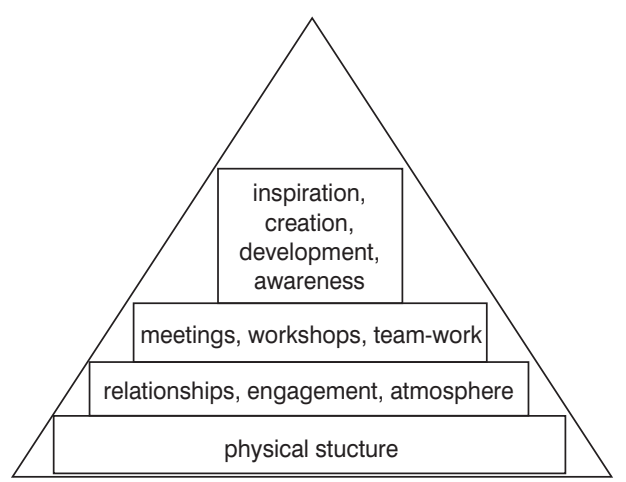

Source: own elaboration based on research

Figure 1 briefly presents the main student expectations towards the university. However, the three bottom parts should be distinguished from the last top part. The bottom ones relate to what Kociatkiewicz and Kostera (2014) classified as a purely practical dimension in management sciences. It refers chiefly to the criterion of usefulness generated by researchers. This functional approach with a long tradition, initiated by Taylor as early as in 1911 , focuses on management indicators such as productivity or efficiency. Accordingly, it concentrates on the organization in the context of functional improvements. Under this approach, in the field of management, the university should focus on practical organizational determinants that support the economic success of a company. Kociatkiewicz and Kostera (2014), however, reveal that this approach has many limitations in generating a real contribution to the development of management sciences. Actions aimed at improving what we already know exclude innovation and discovery. This is because the fundamental problem lies in the fact that "science understood as a service is not able to change the perception of the organization and management processes, focusing solely on improving an a priori model of the social reality" (tamże, 2014). Hence, even those researchers who are recognized in their environments are looking for solutions for contemporary universities in adjusting their curricula/systems to the labour market, thereby narrowing the opportunities offered by the academy (Czapiński, 2014).

Perhaps partly unconsciously, this is acknowledged by the interviewed students. This is evidenced by the top of the pyramid, which contains student expectations that go far beyond purely practical elements. In addition to the needs relating primarily to technical courses, students put an emphasis on their own development. This includes general values that they wish to find in the academic community, but also attitudes to life that they expect from their peers and teachers. This fits in with "a way of perceiving science as a committed action for the common good of all participants in the organization and, even more broadly, for the whole society" (Kociatkiewicz and Kostera, 2014). Under this approach, management sciences go far beyond the practical dimension and reach the "mezzo" level between psychology and sociology. They focus on much broader issues than the restricted area of an organization. Clever students understand the need for a variety of subjects offered during five-year studies, yet they can draw a line between technical and practical courses and those opening the mind, putting an emphasis on thinking and raising awareness about the surrounding reality. Thus, their expectations often went beyond the extremely narrow (though now common) understanding of university studies as get- 
ting through a multitude of classes and lectures with minimal effort. Many students realize that learning does not involve only obtaining credits for the various courses, thus treat student life as comprising many dimensions. They do not expect a unilateral action ("tell us what to do") but actively participate in the life of academic communities to reap multiple benefits. They talked about developing awareness and mentality and university assistance in their own development. They sought inspiration in order to ultimately change the reality. Such an understanding of university studies is inseparable from the development of imagination (Brzozowska and Postuła, 2013) and other humanistic values.

At the present moment of the management education evolution in Poland, we are, nevertheless, aware that not all students see all levels of the pyramid. While the vast majority of them agree with the needs and expectations in the bottom part, only few see the top. As described in the introduction, this is one of the fundamental limitations of contemporary management education. Huge commitment is necessary to build the university as a place for exchanging thoughts and creating new ideas, establishing students' own identity and that of the university, and opening minds. Today, such a direction is excluded because a multitude of students do not identify themselves even with a half of the pyramid presented. There are students who say openly that they went to the university to obtain a certificate. And people who have graduated following this approach and received their diplomas form a crowd. That is why the value of a university diploma is deteriorating so rapidly, as discussed extensively by Alvesson (2013). For obvious reasons, this is a road to nowhere and many contemporary trends should be counteracted. This is not, however, easy mainly for economic reasons, hence it is difficult to introduce novelties in the current system. Although many authors such as M. Kostera (2014), M. Alvesson (2013) and K. Leja (2013) write about the need for changes, these are not implemented by university heads in a fast and efficient manner for the above-mentioned reasons.

\section{References}

Alvesson, M. (2013). The Triumph of Emptiness. Consumption, Higher Education, and Work Organization. Oxford: Oxford University Press.
Brzozowska, A. i Postuła, A. (2013). Czy informatycy potrzebują wyobraźni? In: M. Kostera (ed.), Organizować z polotem. Wyobraźnia organizacyjna w praktyce. Warszawa: Sedno.

Bykowski, P., Szeluga-Romańska, M., Tomczak, M. i Ziemiański, P. (2012). Raport. Badanie losów zawodowych absolwentów Politechniki Gdańskiej. Rocznik 2010. Gdańsk: Wydawnictwo Politechniki Gdańskiej.

Czapiński, J. (2014). Pan magister na kasie w hipermarkecie. Gazeta Wyborcza, 15-16 marca, 28-29.

Czarniawska-Joerges, B. (1992). Exploring complex organizations. A cultural perspective. Newbury Park, London, New Delhi: Sage.

D'Andrea Tyson, L. (2005). On 'Managers not MBAs'. Academy of Management Learning \& Education, 4/2, 235-236.

Hatch, M.J. (2002). Teoria organizacji. Warszawa: Wydawnictwo Naukowe PWN

Kostera, M. (2014). Occupy management! Inspirations and ideas for self-organization and self-management. London: Routlege.

Kostera, M. (2011). Wprowadzenie: Studium przypadku w edukacji menedżerskiej. W: M. Kostera (red.) Organizacje w praktyce. Studia przypadku dla studentów zarządzania. Warszawa: Poltext.

Kostera, M. (2005). Antropologia organizacji: Metodologia badań terenowych. Warszawa: Wydawnictwo Naukowe PWN.

Koźmiński, A.K. (2011). The new revolution in management education? Master of Business Administration, 4, 2-6.

Koźmiński, A.K. (2008). Koniec świata menedżerów. Warszawa: WAiP.

Kociatkiewicz, J. i Kostera, M. (2014). Zaangażowane badania jakościowe. Problemy Zarzadzania, 12, 1(45), 9-17.

Leja, K. (2013). Zarządzanie uczelnia. Koncepcje $i$ wspótczesne wyzwania. Warszawa: Wolters Kluwer Polska.

Shaw, M.M. (2013). Impacts of globalization on the academic profession: Emerging corruption risk in higher education, in: Global corruption report: Education. New York, London: Transparency International, Routledge.

Taylor, F.W. (1911). Principles of scientific management. New York: Harper \& Brothers.

Willis P. (2005), Wyobraźnia etnograficzna. Kraków: Wydawnictwo Uniwersytetu Jagiellońskiego.

Wieczorkowska-Wierzbińska, G. (2011). Psychologiczne ograniczenia. Warszawa: Wydawnictwo Naukowe Wydziału Zarządzania UW. 